\title{
THE DESCRIPTION OF PARENTS' PSYCHOLOGICAL CONDITIONS IN ACCOMPANYING CHILDREN TO LEARN DURING THE IMPLEMENTATION OF STUDY FROM HOME (SFH) IN MAKASSAR CITY AND GOWA REGENCY
}

\author{
Eva Meizarra Puspita Dewi ${ }^{1}$, Eka Damayanti ${ }^{2}$, Andi Halimah ${ }^{3}$, Novita Maulidya Jalal ${ }^{4}$ \\ 1,3,4Fakultas Psikologi, Universitas Negeri Makassar \\ ${ }^{2}$ Fakultas Tarbiyah dan Keguruan, Universitas Islam Negeri Alauddin Makassar \\ Email: evabasti@yahoo.com² ${ }^{1}$,eka.damayanti@uin-alauddin.ac.id² ${ }^{2}$ andihalimah@unm.ac.id ${ }^{3}$, \\ novitamaulidyajalal@unm.ac.id ${ }^{4}$
}

\begin{abstract}
:
This study aims to investigate the psychological conditions of parents in assisting children in learning during the implementation of Study from Home (SFH) in Makassar City and Gowa Regency. This study used quantitative survey research. The samples were 159 parents who were selected by random sampling. The instrument used was a questionnaire containing closed, semi-closed, and open-ended questions distributed using Google forms. The collected data were analyzed using descriptive statistics. The results showed that parents considered SFH as a moment to accompany and be closer with their children. The parents' perception of online learning was less effective (36.8\%) for their children because of limited internet access (57.9\%), many distractions from home (34\%), and the parents did not understand the matter (17.6). The children's complaints during SFH were: not being able to play and do homework in groups (37.1\%), lot of tasks (homework) (32.1\%), preferred taught by teachers directly (29.6\%) and felt bored (29.6\%). The parents perceived SFH as follows; feeling comfortable with family (62.9\%), bored with routine (31.4\%), increased workload (18.9\%). However, the physical complaints were less because the parents' role was powerful in accompanying the children during SFH. Moreover, the family harmony increased with this moment.
\end{abstract}

\footnotetext{
Abstrak:

Tujuan dari penelitian ini adalah untuk memperoleh gambaran kondisi psikologis orang tua saat mendampingi anak belajar selama Study from Home (SFH) di Kota Makassar dan Kabupaten Gowa. Penelitian ini merupakan penelitian kuantitatif jenis survey. Jumlah sampel yakni 159 orang tua yang terpilih secara random sampling. Pengumpulan data menggunakan kusioner yang berisi pertanyaan tertutup, semi tertutup dan pertanyaan terbuka yang disebarkan menggunakan google formulir. Data yang terkumpul dianalisis menggunakan statistik deskriptif. Hasil penelitian menunjukkan bahwa SFH dimaknai oleh orang tua sebagai moment untuk mendampingi dan lebih dekat dengan anak. Orang tua merasakan metode daring kurang efektif $(36,8 \%)$ bagi anaknya, sebab: akses internet yang terbatas $(57,9 \%)$, banyak gangguan dirumah (34\%), dan orangtua tidak memahami materi pelajaran anak $(17,6)$. Keluhan yang dirasakan oleh anak selama SFH adalah: tidak bisa bermain dan kerja kelompok $(37,1 \%)$, banyak tugas $(32,1 \%)$, lebih suka guru yang ajar $(29,6 \%)$, dan bosan $(29,6 \%)$. Adapun orangtua memaknai SFHberupa; perasaan nyaman dengan keluarga $(62,9 \%)$, bosan dengan rutinitas $(31,4 \%)$, beban kerja bertambah (18,9\%). Namun demikian, keluhan fisik tidak terlalu dirasakannya karena peran orangtua sangat kuat dalam mendampingi keluarga selama SFH, bahkan merasa bahwa dengan moment ini keharmonisan keluarga menjadi meningkat.
} 


\section{Keywords:}

Psychological Conditions, Parents, Accompanying Children to Study, Study from Home

How to Cite: Dewi, E. M. P., Damayanti, E., Halimah, A., \& Jalal, N. M. (2021). The Description of Parents' Psychological Conditions in Accompanying Children to Learn During the Implementation of Study from Home (SFH) in Makassar City and Gowa Regency. Lentera Pendidikan :Jurnal Ilmu Tarbiyah dan Keguruan, 24(1), 144-157. https://doi.org/10.24252/lp.2021v24n1i14.

\section{INTRODUCTION}

The Coronavirus or Covid-19 is a pandemic that occurs in almost all countries in the world. New cases of coronavirus infection and deaths due to Covid-19 continue to be reported in various countries around the world. As reported from www.worldometers.info, on April 17th, 2021, there were 140.502 .025 cases of Covid-19. Based on the total cases, 119.321.085 cases have been declared cured, and 3.011.457 cases declared dead (Worldometers.info, 2021).

The United States is the country with the highest positive cases of Covid-19, followed by India and Brazil. Indonesia is also infected with the covid 19 virus, which became the highest country with the most positive cases in ASEAN. There are 1.594.722 cases with the number of patients who died as many as 43.196 people, and the number of successfully cured patients ranged from 1.444.229 people. Based on the obtained data from www.covid19.go.id, it is found that the Special Capital District (DKI) of Jakarta region became the highest in Indonesia with the number of positive patients as many as 397.088, followed by West Java Indonesia with the number of positive patients as many as 265.286 (covid19.go.id, 2021).

Since March 17th, 2020, the government has enacted Work From Home (WFH), which stipulates and establishes that workers currently have to work from home. Therefore, it is recommended to minimize the spread of the Covid-19 virus. The policy of Work from Home (WFH), activities, or work is done online. The policy has implications for all aspects of Indonesian people's lives, and one is in the educational sector.

Massive changes have occurred in the educational sector. Handhika, Fatmayanti, Winarti, Buarti, Khasanah, and Viyanti (2020) said that circulars issued by the Minister of Education and Culture Number 3 of 2020 regarding the prevention of Covid-19 in Education Units and Number 36926/MPK.A/HK/2020 concerning online learning, educators are expected to present a fun learning process for students. They also make circulars with the same content at the university level, namely implementing online learning on campus. Online learning set by the government is aimed at all educational levels from kindergarten to college.

The government selected this alternative to learn online or daring supported due to the growing industrial revolution 4.0. The development of the industrial revolution in the educational sector supports implementing online learning from home. Putra \& Irwansyah (2020) explained that online learning is learning that eliminates time and distance with the help of internet-based digital platforms that can support learning to be 
done without any physical interaction between educators and students. The implementation of Study from Home (SFH) involves technology in the 4.0 era and requires contributions from teachers and parents in the application of online learning. However, not all parents are ready to assist their children's learning process at home due to the covid 19 pandemic.

Anshori's research (2020) showed that online learning could have an impact on children, including: (1) the students who are required to study independently at home without mental preparation, as well as the infrastructure availability that is conducive to optimize online learning; (2) all students have no the same facilities related to the procurement of facilities for online learning such as the smartphones, computers, and laptops; and (3) online learning has an impact on students' mentality so that the opportunity for social interaction of fellow friends is reduced.

Tabi'in (2020) also argued that the impacts caused during Study from Home (SFH) are: The children are easier to feel depressed or stressed, sensitive; They become spoiled and not independent, as well as behavior changes due to children staying at home too long; The children feel tired due to many tasks (homework) from school; They cannot learn well; The children's feelings are volatile, difficult to be advised, and they have behavioral disorders.

Online learning not only impacts the students generally but also their parents. Wardani and Ayriza (2021) revealed that parents have difficulty accompanying students to learn online at home, have difficulty fostering children's learning interests, and lack material understanding. They become impatient to accompany the children while studying at home and have no time to accompany them because they have to work. The parents also get difficulty in operating gadgets and get constraints related to the reach of internet services.

Anshori (2020) also outlines similar problems of the impact of online learning on parents, including; (1) Parents increase spending the internet data purchases; (2) They take extra time to accompany a child to learn because not all children can be independent to learn on their own, sometimes they also need assistance and demands to do something; (3) Parents reduce their activity time because they must have extra time to accompany their children; (4) They must establish communication with children's teacher to report their children's development while learning at home. Similarly, Tabi'in (2020) revealed that Study from Home (SFH) also affects parents who become impatient in accompanying children to learn and play.

Studying from home (SFH) is a step that has a positive and negative impact. The impacts on parents are: (1) the additional cost of purchasing internet quota, online technology requires a network connection to the internet; therefore the level of internet use will increase parental expenses; (2) parents should spend more time with the children accompanying online learning, and they should share time with their children in online learning; (3) parents must also use technology so that they must be ready to learn and teach remotely using technology (Purwanto, Pramono, Asbari, Santoso, Wijayanti, 
Hyun, \& Putri, 2020). In addition, Kurniati, Alfaeni, and Andriani (2020) assumed that one of the impacts of Study from Home (SFH) is parents have to be educators, mentors, carers, and supervisors. They specifically should be able to divide time to accompany children in online learning and control the tasks given by teachers.

The impact of study from home (SFH) is certainly felt by parents, such as (1) parental expenses are greater than usual because of credit and internet connection; (2) parents are required to master technology to support the learning process at home; (3) parents are required to think creatively to try various ways so that the child does not feel saturated while studying at home.

One of the parents' obligations is that parents should take the time to accompany and provide support to the child when studying at home. Novrinda, Kurniah, and Yulidesni (2017) assumed that the efforts and responsibilities to the needs and fulfillment of children's rights become the duty of parents in fulfilling rights. Ambaryanti (2013) also believed that parental supervision and guidance at home are needed because of the guidance parents can supervise and know all the shortcomings and difficulties of children in learning. Parents play a big role in teaching, educating, guiding, and providing learning facilities and setting an example for their children.

Online learning became the solution during the Covid-19 pandemic. Still, on the other hand, some obstacles felt by parents after the enactment of study from home (SFH) during the Covid-19 pandemic. They have to spend more time accompanying children to learn online at home. Research conducted by Purwanto, Pramono, Asbari, Santoso, Wijayanti, Hyun, \& Putri (2020) showed that parents during the Covid-19 pandemic accompanied their children during their studies. Accompanying children in online learning would certainly affect the daily routine work activities. Parents who have difficulties with their work and accompanying their children to learn at home express their feeling to their children's teachers. However, many parents are also very appreciative because their experience teaching two children at home is challenging; moreover, the teachers have to teach 20 students in the class.

Students' readiness to participate in distance learning programs and use the elearning system are important indicators in implementing e-learning programs. Raaij \& Schepers (2008) stated that individual differences in the use of online learning are an essential aspect and the design of virtual learning itself. Psychological factors in online learning are a broad psychological study especially related to the psychological condition of children, parents, and teachers involved in its implementation.

A study conducted by Rahayu (2018) revealed that the relationship of parents and children in the South Sulawesi showed how to implement the values of local wisdom in shaping the character of early childhood, namely through examples of discipline, habits, advice, attention, and affection. Goossens and van Ijzendoorn in Boland (2011)assumed that children who have a secure attachment with caregivers tend to have a positive relationship with the teacher. Boland (2011) revealed that the home environment in helping the learning process predicts the child's readiness to learn. Six factors support children's success in learning as follows: 1 ) Parenting, parents are involved in making 
children happy, healthy, and skilled; 2) Communicating, families and schools establish communication with each other related to the smooth study of children and the health condition of the child; 3) Volunteering, selecting, and organizing parental assistance and support for school programs and student activities; 4) Learning at home, providing ideas and information to parents about the way they can accompany children to do homework and activities related to the curriculum; 5) Decision making, parents participate in school decision making and create parent associations that support and give considerations in the schools' program; and 6) Collaborating with the community, identifying communities that can support and strengthen the role of schools, students, and families (Durisic \& Bunijevac, 2017).

Students who have high academic achievement prescribe their parents more protective and loving, and their parents give sympathetic expressions, emotional appreciation, and psychologically safe feelings. In contrast, children with low academic achievement tend to perceive parents to reject the child's existence, neglect, obnoxious symbols, and objects of punishment (Toor, 2018). Based on these findings, it can be explained that parent-child relationships influence academic achievement in junior high school students. Toor (2018) also found that students perceive their parents in the parent-child relationship dimension based on gender, school type, and academic achievements. Social context also plays a role in shaping the relationship between parent and child.

A strong relationship between school and family in assisting the child in developing the skills needed to succeed socially and emotionally, academically, and establish significant factors in the overall academic achievement of the child (Christenson \&Hirsch, 1998; Mashburn \&Pianta, 2006; in Edwards, Sheridan, \& Knoche, 2008). It can be concluded that the success of children's learning is determined by the cooperation between family and the school, in this case, the role of parents and teachers. One of the focuses of this research is the Involvement of parents in accompanying children to learn during the study from home (SFH). The study from home (SFH) policy demands good cooperation between parents and teachers. Various strategies are needed, including adopting local cultural values in the learning process to face current conditions. Based on the study result from Syarif, Sumarmi, Fatchan, and Astina (2016) stated that Makassar culture, one of the local wisdom that grows and develops among the Bugis Makassar community, has important elements that can increase students' learning motivation, namely the concept of Siri' and Pacce. If used properly in the learning process, this concept can be a strong motivator for students to improve their skills learning achievement. The interesting thing about this study was the description of the psychological condition of parents in accompanying children to learn during the implementation of Study from Home (SFH) in Makassar city and Gowa regency.

\section{RESEARCH METHOD}

This research used quantitative research with a survey. The absolute truth of knowledge in regards to human behavior may never be fully understood. It is essential to 
create an objective survey instrument that provides a numeric measure of observed behaviors (Creswell, 2014). The population was parents domiciled in Makassar and Gowa districts because these two locations were the highest positive areas and Patient under Surveillance (PUS) of Covid-19 in South Sulawesi. Moreover, all of the schools of these two districts was carried out through online learning. The samples were 159 parents selected by using random sampling and who were willing to fill out the questionnaire through google form provided in the social media. The criteria of the sample selected as follows; (1) Domiciled in Makassar or Gowa district; and (2) Have school-age children (elementary, junior high, and or high school). This research instrument was a questionnaire containing closed, semi-open, and open questions distributed through google forms for seven days. It related to the parents' and children's perception of Study from Home (FSH). The data obtained were analyzed using descriptive statistics. Besides, researchers also used coding analysis of open questions to the quantify results.

\section{RESULTS AND DISCUSSION}

\section{Children's Complaints during Study from Home (SFH)}

The following are presented the result of childrens' complaints during online learning. They felt bored (47\%), preferred to be taught by teachers directly (47\%), experienced excessive workloads (51\%), and most of them complained about not being able to play with their friends (59\%). The graph presented as follow:

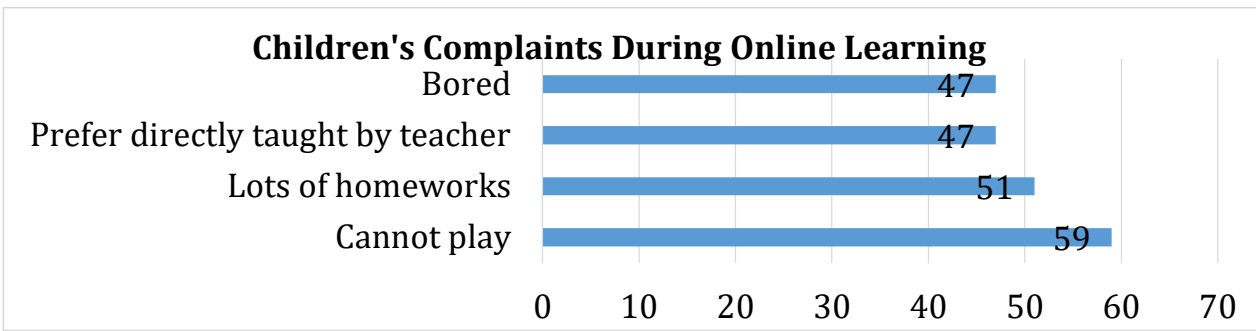

Figure 1. Students' Complaints during SFH

\section{Problems Encountered during Study from Home (SFH)}

The children experienced several problems during SFH. The biggest obstacles encountered by the children during online learning were such as limited internet access (92\%), distractions from home so they cannot focus (54\%), not understanding the material taught by the teacher (28\%), and limited supporting facilities (28\%).

\section{Online Activity Issues}

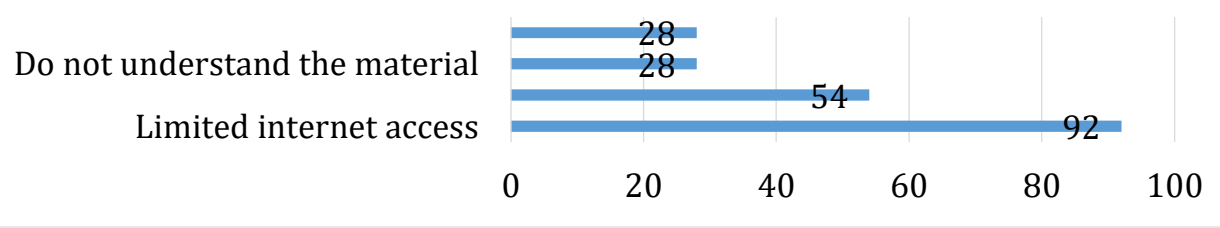

Figure 2. Issues encountered in Online Activities 
Online learning during SFH is a surprising moment among teachers, students, and parents. The learning process suddenly changed from face-to-face to online that caused many things to prepare, starting from the curriculum, the teaching methods, and learning tools: connection, smartphone, laptop, and quota. The results showed the most problematic was the limited internet access based on this study. Another distraction was parents did not understand the child's learning materials, so that the child was confused and not optimal in understanding the lesson delivered by the teacher. This condition made online methods felt ineffective for students and parents. Teachers also felt less optimal and less motivated with online forms because they could not face this condition. Boland (2011) revealed that the home environment in helping the learning process predicted the child's readiness to learn. Parents can support children's success in learning if parents are involved in making children happy.

\section{Parents' Perception of Their Childrens' Complaints during Study from Home (SFH)}

Parents perception of the complaints felt by children during Study from Home (SFH) were: children were not able to play and work in groups (37.1\%), children had a lot of tasks (homework) (32.1\%), children preferred teachers to teach directly $(29.6 \%)$, and children felt bored (29.6\%). Childhood and adolescence are the times when socialize and get friends that are so important. When a child can no longer go to school, something is lacking in his/her life, such as joys to meet and play with friends. In the work of the task, the students usually help each other and discuss. It does not happen during SFH. Moreover, there is a lot of assignments accepted by students. Teachers are unfamiliar with online tasks, giving more assignments assuming that the students will understand the material delivered online. The condition of the students is very bad because they do not interact with their friends, a lot of tasks but parents cannot help to complete their duties, so this makes them eager to go back to school and study with the teacher directly. Learning at home makes children feel bored.

\section{Children's Perception during Their Parents Accompanying Them to Study from Home (SFH)}

Children experienced varying feelings when accompanied by their parents during study from home (SFH). Based on data analysis, the result as follows; feeling comfortable with family (62.9\%), bored with routine (31.4\%), increased workload (18.9\%). However, physical complaints were not felt too much because the parents' role was powerful in accompanying the children during SFH.

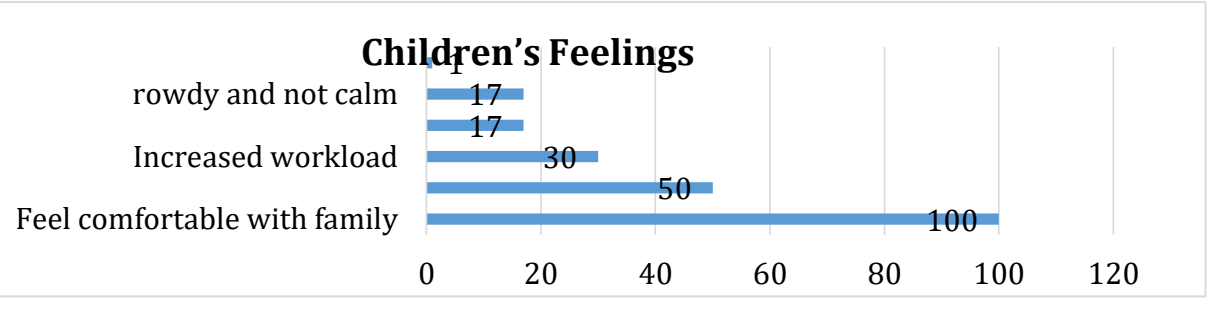

Figure 3. Children's Feelings during SFH 


\section{Parents' Perception during Accompanying Children to Study from Home (SFH)}

The results of this study showed that parents considered Study from Home (SFH) as a moment to accompany and be closer to their child. This situation is natural because parents are usually half a day, even more, separated from their children because they are in school to study from home (SFH) in 24 hours at home. The parents also responsible become teachers at home. Likewise, parents usually go to the office, but in their time working from home (WFH), the parents focus on office work and help their children in online learning. In the beginning, they may feel this condition is very excruciating. Still, after trying to adapt and accept the rhythm of learning children, parents realized that the role was very important by involving themselves and accompanying their children in learning at home. The following graph presents the parents' perception while accompanying their children learning online:

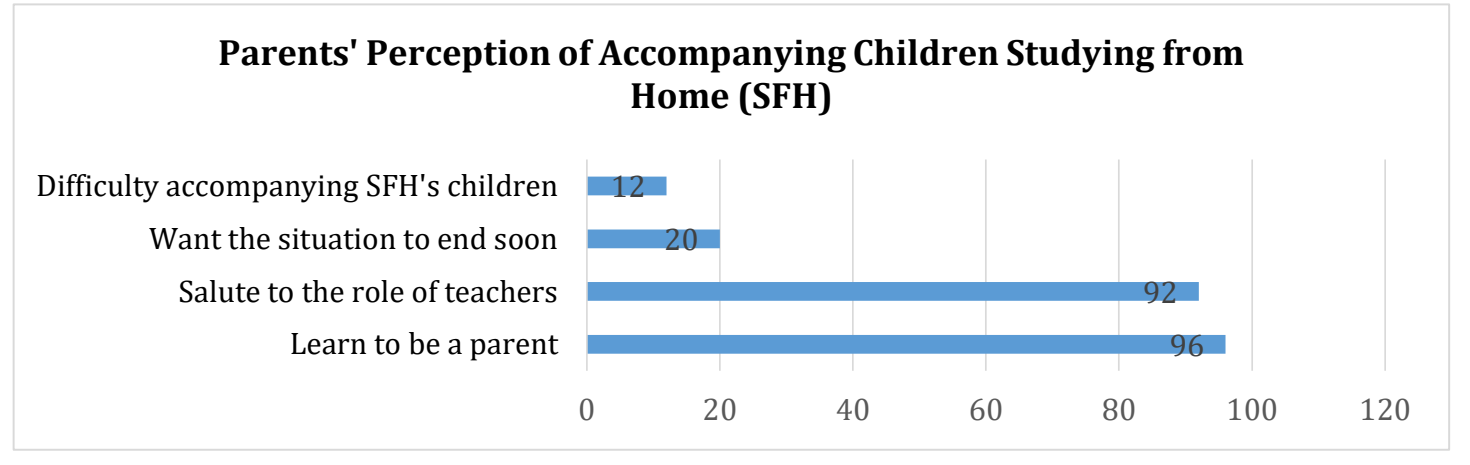

Figure 4. Parents' Perception of Accompanying Children during SFH

\section{Parents' Experiences during Study from Home (SFH)}

Parents experienced joy and sorrow while accompanying their children studying from home. The following is the responses obtained from their experience while accompanying their children learning online: 1) Emotional management: 35 responses (22\%); 2) Time management: 23 responses (14.4\%); 3) Facilities for access: 19 responses (11.9\%); 4) Assistance/guidance: 18 responses (11.3\%); 5) Parental control: 12 responses $(7.5 \%)$; 6) Learning guide: 10 responses (6.2\%); 7) Material mastery efforts: 9 responses (5.6\%); 8) Flexible: 6 responses (3.7\%); 9) Digital skills: 5 responses (3.1\%); and 10) Motivation: 4 responses (2.5\%).

The result indicated that emotional management had a strong role while parents accompany their children in learning online. When parents are busy and depressed with the situation of sharing attention with the child, emotions are not controlled, so it is irritable and spoils the atmosphere of home comfort. Therefore, emotional management becomes the main key following the time management that must be optimal so that all parental duties can be completed properly. Another main thing that parents need to pay attention to for their children to succeed in online learning is internet access. In online learning, the main key is on the internet network. Learning cannot run well if the internet facilities are not optimal. Therefore, the school should also consider whether all its students are in an environment with a good internet network. Students will feel stressed 
and discouraged if they cannot follow the learning well or deny facing this difficult situation so that the children's motivation of learning down.

The research results revealed that learning online during the Covid-19 was interpreted by parents as a moment to accompany and be closer to the children. Parental Involvement in attending children to learn online at home is one of the roles of parenting that plays an essential role in fulfilling the child's developmental tasks. John Bowlby argued in his attachment theory that a child develops internal representations of relationships as a result of interactions with his parents. A study conducted by Kurniati, Alfaeni, and Andriati (2020) showed that parents play an important role in accompanying children to study from home because all of the learning processes needed to be assisted by parents.

This attachment theory also revealed that parent-child relationships have a longterm effect in shaping psychological functions in children. Since infancy, parent and child relationships are characterized by bonding with parents, especially mothers. Bonding forms the emotional and physical power between the child and his parents. Loss of figure attachment is related to anxiety and sadness, which then triggers problems in socioemotional development in children. On the contrary, a strong attachment between parent and child is necessary for the child's mental health in adulthood (Popov \& Ilesanmi, 2015).

The study conducted by Moore, Kinghorn, \& Bandy (2011) found that good relationships between parents and children correlate with the achievement of results obtained by children in the delivery of social competence, learning attachment in school, and parent-child communication. It can happen during the process of parents accompanying children to learn online during the Covid 19 outbreak.

Furthermore, Popov dan Ilesanmi (2015) also explained that parent-child relationships that occurred between parents and children online could be influenced by several factors such as antisocial and externalizing behavior, temperament, negative affection, family structure, and parenting type.

The parents can be friends and teachers for any problems experienced by children. In this study, the most complaints felt by children during the study from home (SFH) were not being able to play and not working in groups. Therefore, Senechal dan LeFevre (2002) introduced home literacy activities consisting of formal and informal learning activities involving parents. Children's early literacy skills develop rapidly with informal literacy activities with parents. For example, parents read storybooks, and children ask about new vocabulary in the book told, while formal literacy activities when parents provide printed letters and labels. The Home literacy model presented by Senechal and LeFevre emphasizes the interaction of parents and children in achieving success in learning so that learning activities at home can be successful if parents and children can interact well.

Mansour \& Martin (2009) found that home and parent factors play important roles in improving students' motivation and attachment in learning. The study revealed that 
existing resources in the home environment and parenting patterns were positively correlated in planning, task management, teacher-student relationships, and negative correlations with self-handicapping. The theory put forward by Deci and Ryan (Mansour \& Martin, 2009) about Self-determination theory is used in explaining the motivation and attachment of students in learning, including competence, autonomy, and connectedness. Competence refers to the way individuals achieve external and internal results for their success in implementing the right actions needed to achieve the goal. Autonomy refers to the individual's internal locus in applying behavior. While, connectedness refers to the individual's feelings of safety and positive attachment to the person closest to him. Specifically, in the connectedness dimension, the role of parents makes the child feel safe and comfortable to shape the development of academic ability.

Learning conducted by parents at home toward children in learning activities in an environment close to the child seems to affect their learning achievement positively. Many researchers such as Evans, Shaw, \& Bell, 2000; Scarborough \& Dobrich, 1994; Senechal \&LeFevre, 2002 in Skwarchuk, Sowinski, \& LeFevre (2014) has been linking between the quality of the home environment and the achievement of social and academic abilities in children. Specifically, the effective learning process at home in the environment related to literacy at the first level shows consistent results.

Children's relationships with parents and other families can affect their developmental achievements. Positive parent-child relationships are shown to contribute to emotional, social abilities, greater child security, and warmer and connected parentchild relationships. On the other hand, negative parent-child relationships can lead to more love affair anxiety in a child's future life and many emotional stressors. In addition, they can cause adverse mental health problems in the future (Stardis et al., Cummings \& Deavies, Friesen, Seiffge-Krenke, et al., Mallers et al. in Grant \& Carlson (2018). Gunarsa (2004) assumed that healthy emotional attachment with parents could prevent feelings of anxiety and depression in children and adolescents. Based on this research results, it is known that parents' perception related to the children complaints during studying from home (SFH) include children not being able to play and working in a group (37.1\%), a lot of tasks (homework) (32.1\%), preferring teachers to teach them $(29.6 \%)$, and bored (29.6\%). Thus, parents assisting their children can affect the emotional closeness between parents and children, improve their mental health, and decrease complaints from children during the study from home (SFH).

Mulyadi, Rahardjo, and Basuki (2016) explained that a healthy relationship between parents and children could provide comfort at home to children. It can also improve communication and strengthen the emotional relationships established with parents. Parents can act as parents and friends for children to support and accompany children in living and managing various difficulties in life. A healthy relationship between parents and children can be seen from the communication built between the two. This statement is in line with Wahyuti dan Syarief (2016) opinion that the attachment of the relationship between children and parents is strongly influenced by the quality of interpersonal communication between parents and children. A simple form of 
interpersonal communication that can be done is approaching relationships by paying attention and supporting each other when children study at home (FSH) and parents working at home (WFH). This study result indicated that parents as a moment accompany their children and getting closer to them. It is natural because parents who usually have half a day, even more, separated from their children because the children are in school, now during SFH in 24 hours, the parents work at home.

Mulyadi, Rahardjo, and Basuki (2016) conducted research involving 87 subjects who participated in homeschooling programs in Tangerang. The first finding was that parent-child relationship factors could predict academic stress indirectly through selfefficacy factors. The second finding was that parent-child relationship factors could predict academic stress through self-esteem factors. Thus, based on Mulyadi, Rahardjo, \& Basuki (2016) research, parents play an essential role in building positive self-esteem related to homeschooling activities. In addition, a study from home (SFH) requires parental support as a protective factor in reducing academic stress in children.

Wardhani \& Krisnani (2020) believed that parents with adequate educational backgrounds and supported by complete facilities might not be a big problem when accompanying children to study at home. However, for parents whose education level is inadequate, becoming teachers for their children is not easy. Besides, limited access to information is also an obstacle for some parents in guiding their children. This condition is in line with the results of this study that parents felt online methods were less effective $(36.8 \%)$ for their children, because of limited internet access (57.9\%), many disturbances at home (34\%), and parents do not understand the children's subject material $(17.6 \%)$. In addition, the research results from Wardani \& Ayriza (2021) also showed that the general constraints of parents in accompanying children to study at home during the Covid-19 pandemic, including: lack of understanding of the material; difficulty to foster children's learning interests; having no enough time to accompany the child because they have to work; impatient to accompany the child while studying at home; challenging to use gadgets; and problems related internet services.

\section{CONCLUSION}

This research revealed that: (1) Online methods during Study from Home (SFH) are considered less effective; thus the children preferring face-to-face learning; (2) The Study from Home (SFH) turns out to have a positive impact if the parents want to cooperate in accompanying the child, to increase family harmony; (3) Many parents feel overwhelmed to questions because they do not master the material; (4) Students believed that the study from home(SFH) become unpleasant because they cannot meet friends, get a lot of tasks, feel boredom, and teachers cannot lead them well in discussing materials.

Therefore, the results of this research produced practical recommendations: (1) Teachers need training in designing an interesting online learning process so that the teacher will not give tasks frequently, but there is an interaction with students in the discussion of materials; (2) Continuing the habits that have been established, it is the 
cooperation of parents in accompanying children to learn; (3) The school shall provide a briefing to parents or prepare strategy so that parents have skills to accompany children to learn; (4) The teacher starts with blended learning which means that the children remain on the portion to use Information Technology in their learning because they are preparing for facing the 5.0 era.

\section{REFERENCES}

Ambaryanti, R. (2013). Hubungan Intensitas Pendampingan Belajar Orang Tua dengan Kualitas Hasil Belajar Siswa di RA Al-Islam Mangunsari 02 Semarang Tahun Pelajaran 2011/2012. Indonesian Journal of Early Childhood Education Studies, 2(2). https://doi.org/10.15294/IJECES.V2I2.9240.

Anshori, I. dan Z. I. (2020). Dampak Covid-19 Terhadap Proses Pembelajaran Di MTS AlAsyhar Bungah Gresik. Islamic Management: Jurnal Manajemen Pendidikan Islam, 3(2), 181-199. http://dx.doi.org/10.30868/im.v3i2.803.

Boland, A. M. (2011). Exploring the relationship between home and school experiences and kindergarten readiness for higher and lower income preschoolers. Dissertation. The Ohio State University.

covid19.go.id. (2021). Peta Sebaran. Komite Penanganan Covid-19 Dan Pemulihan Ekonomi Nasional. Retrieved from https://doi.org/https://covid19.go.id/petasebaran.

Creswell, J. W. (2014). Research design. (4th ed.). Los Angeles, CA: Sage. D' Antona, R., Kevorkian, M., \& Russom, A. (2010). Sexting, texting, cyberbullying and keeping youth safe online. Journal of Social Science, 6(4), 523-528. https://doi.org/10.3844/jssp.2010.523.528.

Durisic, M., \& Bunijevac. (2017). Parental Involvement as a Important factor for successful education. Research Insights and Challenges for Facilitating Critical Thinking, 7(3), 137-153. https://ojs.cepsj.si/index.php/cepsj/article/view/291.

Edwards, C. P., Shaeridan, S. M., \& Knoche, L. (2008). Parent engagement and school readiness: parent-child relationships in early learning. In Child, Youth, and Family Studies. Depatment of Child, Youth, and Family Studies. https://digitalcommons.unl.edu/cgi/viewcontent.cgi?article=1060\&context=fam confacpub.

Grant, A., \& Carlson, M. J. (2018). Parent-child relationship quality and children's behavioral outcomes: do close relationships matter? Atricle. University of Wisconsin-Madison.

https://paa.confex.com/paa/2018/mediafile/ExtendedAbstract/Paper24209/Gr ant_Carlson_PAA_2018.pdf.

Gunarsa, S. D. (2004). Bunga Rampai Psikologi Perkembangan: Dari Anak Sampai Usia Lanjut. Jakarta: BPK.

Handhika, J., Fatmaryanti, S. D., Winarti, Budiarti, I. S., Khasanah, N., \& Viyanti. (2020). Pembelajaran Sains di Era Akselerasi Digital. Magetan, Jawa Timur : CV AE Media Grafika.

Kurniati, E., Alfaeni, D. K. N., \& Andriani, F. (2020). Analisis Peran Orang Tua dalam Mendampingi Anak di Masa Pandemi Covid-19. Jurnal Obsesi: Jurnal Pendidikan Anak Usia Dini, 5(1), 241-256. https://doi.org/10.31004/obsesi.v5i1.541. 
Mansour, M., \& Martin, A. J. (2009). Home, Parents, and Achievement Motivation: A Study of Key Home and Parental Factors that Predict Student Motivation and Engagement. The Australian Educational and Development Psychologist, 26(2), 111-126. https://doi.org/10.1375/aedp.26.2.111.

Moore, K. A., Kinghorn, A., \& Bandy, T. B. S. (2011). Parental Relationship Quality and Child Outcomes Across Subgroups. ChildTrends Research Brief. https://www.childtrends.org/wp-content/uploads/2011/04/Child_Trends2011_04_04_RB_MaritalHappiness.pdf.

Mulyadi, S., Rahardjo, W., \& Basuki, A. M. H. (2016). The Role of Parent-child Relationship, Self-esteem, Academic Self-efficacy to Academic Stress. Procedia Social and Behavioral Sciences, 217, 603-608. https://doi.org/10.1016/j.sbspro.2016.02.063.

Novrinda, Kurniah, N., \& Yulidesni. (2017). Peran orang Tua dalam Pendidikan Anak Usia Dini Ditinjau dari Latar Belakag Pendidikan. Jurnal Ilmiah Potensia, 2(1), 39-46. https://doi.org/10.33369/jip.2.1.39-46.

Popov, L. M., \& Ilesanmi, R. A. (2015). Parent-Child Relationship: Peculiarities and Outcome. Review of European Studies, 7(5), 253-263. https://doi.org/10.5539/res.v7n5p253.

Purwanto, A., Pramono, R., Asbari, M., Santoso, P. B., Wijayanti, L. M., Hyun, C. C., \& Putri, R. S. (2020). Studi Eksploratif Dampak Pandemi COVID-19 Terhadap Proses Pembelajaran Online di Sekolah Dasar. EduPsyCouns: Journal of Education, Psychology and Counseling, 2(1), 1-12. Retrieved from https://ummaspul.ejournal.id/Edupsycouns/article/view/397.

Putra, R., \& Irwansyah, I. (2020). Media Komunikasi Digital, Efektif namun Tidak Efisien, Studi Media Richness Theory dalam Pembelajran Jarak Jauh Berbasis Teknologi di Masa Pandemi. Jurnal Ilmu Sosial Dan Politik, 1(2), 1-13. https://ejournal.upnvj.ac.id/index.php/GlobalKomunika/article/view/1760.

Raaij, E. M. V., \& Schepers, J. J. L. (2008). The Acceptance and Use of a Virtual Learning Environment in China. Computer and Education, 50(3). https://doi.org/10.1016/j.compedu.2006.09.001.

Rahayu, S. (2018). Penanaman Nilai-Nilai Kearifan Lokal dalam Pembentukan Karakter Anak Usia Dini di Kecamatan Marioriwawo Soppeng Sulawesi Selatan. Tesis. Makassar: Program Pascasarjana UNM.

Senechal, M., \& LeFevre, J. A. (2002). Parental Involvement in the development of children's reading skill: A five year longitudinal study. Child Development, 73(2), 445-460. https://doi.org/10.1111/1467-8624.00417.

Skwarchuk, S. L., Sowinski, C., \& LeFevre, J. A. (2014). Formal and informal home learning activities in relation to children's early numeracy dan literacy skills: the development of a home numeracy model. Journal of Experimental Child Psychology, 121, 63-84. https://doi.org/10.1016/j.jecp.2013.11.006.

Syarif, E., Sumarmi, Fatchan, A., \& Astina, I. K. (2016). Integrasi nilai budaya etnis Bugis Makassar dalam proses pembelajaran sebagai salah satu strategi menghadapi era masyarakat ekonomi ASEAN (MEA). Jurnal Teori Dan Praksis Pembelajaran IPS, 1(1). http://dx.doi.org/10.17977/um022v1i12016p013.

Tabi'in, A. (2020). Problematika Stay At Home Pada Anak Usia Dini Di Tengah Pademi Covid 19. Jurnal Golden Age, 4(1), 190-200. https://e- 
journal.hamzanwadi.ac.id/index.php/jga/article/download/2244/1298.

Toor, K. K. (2018). arent-child relationship and students' academic achievement: A study of secondary school students. MIER Journal of Educational Studies, Trends \& Practices.8, $\quad 8(1), \quad 38-56 . \quad$ Retrieved from http://www.kristujayantijournal.com/index.php/mjestp/article/view/1418.

Wahyuti, T., \& Syarief, L. K. (2016). Korelasi Antara Keakraban Anak dan Orang Tua dengan Hubungan Sosial Asosiatif Melalui Komunikasi Antar Pribadi. Jurnal Visi Komunikasi, 15(1), 143-157. https://dx.doi.org/10.22441/jvk.v15i1.1691.

Wardani, \& Ayriza, Y. (2021). Analisis Kendala Orang Tua dalam Mendampingi Anak Belajar di Rumah Pada Masa Pandemi Covid-19. Jurnal Obsesi Jurnal Pendidikan Anak Usia Dini, 5(1), 772-782. https://doi.org/10.31004/obsesi.v5i1.705.

Wardhani, T. Z. Y., \& Krisnani, H. (2020). Optimalisasi Peran Pengawasan Orang Tua dalam Pelaksanaan Sekolah Online di Masa Pandemi Covid-19. Prosiding Penelitian \& Pengabdian Kepada Masyarakat, 7(1), 48-59. https://doi.org/10.24198/jppm.v7i1.28256.

Worldometers.info. (2021). Covid-19 Coronavirus Pandemic. Worldometers. Retrieved from https://www.worldometers.info/coronavirus/\#countries. 